Proc. Estonian Acad. Sci. Geol., 2006, 55, 3, 213-240

\title{
Conodonts of the Kiviõli Member, Viivikonna Formation (Upper Ordovician) in the Kohtla section, Estonia
}

\author{
Viive Viira ${ }^{\mathrm{a}}$, Richard J. Aldridge ${ }^{\mathrm{b}}$, and Stephanie Curtis ${ }^{\mathrm{b}}$ \\ a Institute of Geology at Tallinn University of Technology, Estonia pst. 7, 10143 Tallinn, \\ Estonia; viira@gi.ee \\ b Department of Geology, Leicester University, Leicester LE1 7RH, UK; ra12@leicester.ac.uk \\ Received 13 December 2005, in revised form 7 February 2006
}

\begin{abstract}
Conodont faunas from the kukersites and kukersitic limestones of the Kiviõli Member are similar to coeval collections from other sedimentary facies and there are no taxa endemic to this unusual environment. The presence of Amorphognathus tvaerensis and the absence of Pygodus anserinus suggest that the lower part of the Kukruse Stage is referable to the A. tvaerensis conodont Biozone and that the base of the Upper Ordovician lies at or beneath the base of the Kukruse Stage.
\end{abstract}

Key words: conodonts, taxonomy, biostratigraphy, Kukruse Stage, Ordovician, Estonia.

\section{INTRODUCTION}

The Viivikonna Formation of the Kukruse Regional Stage is the main stratigraphic unit containing oil shale (kukersite) in the Ordovician strata of Estonia (Fig. 1). Kukersite is an economically important rock that accumulated in a large area extending from western Estonia to St. Petersburg in Russia and has been exploited for energy and the chemical industry since 1916. It was formed in shallow subtidal shelf conditions in the Palaeobaltic Sea, on the southern slope of the Fennoscandian Shield (Männil 1966; Männil et al. 1986; Männil \& Bauert 1986). Kukersite is a mixed rock consisting of three main components: organic, carbonaceous, and terrigenous matter. The organic matter content ranges from 10 to $65 \%$ and is composed primarily of the blue-green alga Gloeocapsomorpha prisca. Algal mats were located along the entire coastline, and algal material 


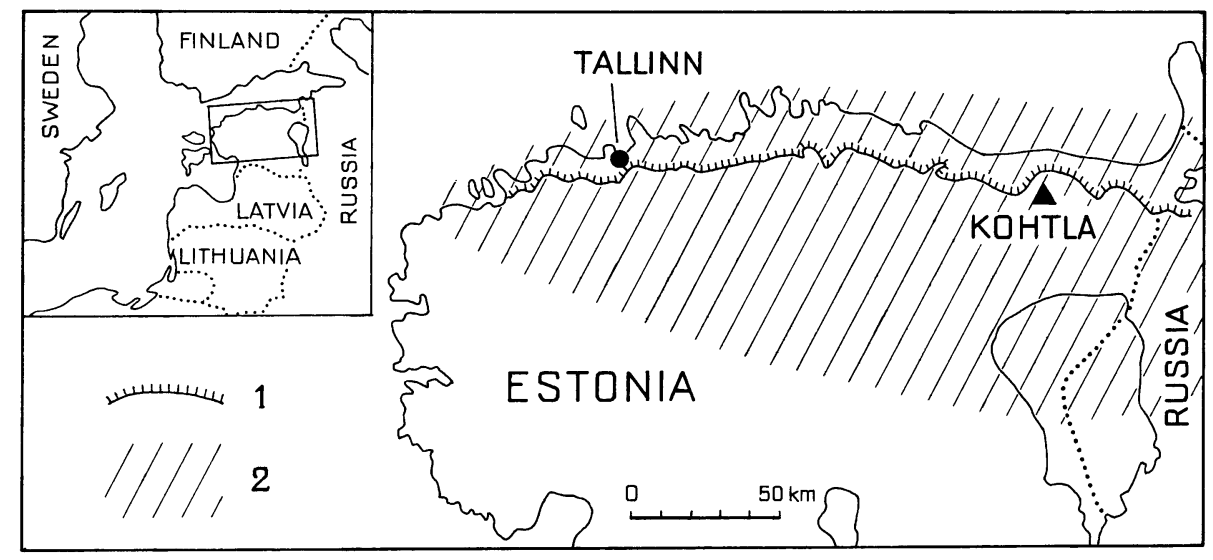

Fig. 1. Map of North Estonia, showing the kukersite accumulation area and the location of the Kohtla section, near Kohtla-Nõmme. 1, outcrop boundary of the Kukruse Stage; 2, area of kukersite organic matter accumulation in late Uhaku and Kukruse time.

was carried into the shelf area by waves and streams (Männil 1990; Kõrts 1992; Saadre \& Suuroja 1993). In contrast to other oil shales, kukersite beds contain a rich and diverse fauna, indicating the presence of well-oxidized bottom waters at the time of organic matter accumulation. The overall lithology of the Viivikonna Formation comprises a sequence of grey more or less argillaceous calcarenitic limestones with intercalations of brownish kukersite (oil shale) and kerogenous marls. The whole oil shale sequence contains abundant hardgrounds or discontinuity surfaces, especially in northern and western Estonia (Bauert 1989; Saadre 1993).

The Viivikonna Formation is subdivided on the basis of the frequency of kukersite seams or the content of the kerogenous component into three members (in ascending order): Kiviõli, Maidla, and Peetri (Fig. 2). The thickness of the formation ranges from 5 to $24 \mathrm{~m}$, with kukersite beds comprising up to $35 \%$. Commercially developed seams are commonly made up of several $10-30 \mathrm{~cm}$ thick kukersite beds.

The Kukruse Stage contains the richest and most diverse macrofauna in the Ordovician of Estonia, with more than 330 species recorded, mainly bryozoans, brachiopods, and trilobites (Rõõmusoks 1970; Hints 1997). The presence of conodonts was mentioned by Bergström (1971).

The detailed stratigraphic nomenclature of the kukersite beds follows a historical tradition of more than 60 years, during which it was developed by various authors. Each kukersite unit is labelled by a capital letter of the Latin alphabet, with individual layers within the unit designated by subscript numbers (e.g. $\mathrm{F}_{1}-\mathrm{F}_{5}$ ). The commercial kukersite seams are those from $\mathrm{A}$ to $\mathrm{F}_{2}$. The kukersite beds alternate with limestone interbeds, which are indexed as $\mathrm{A} / \mathrm{B}$, 


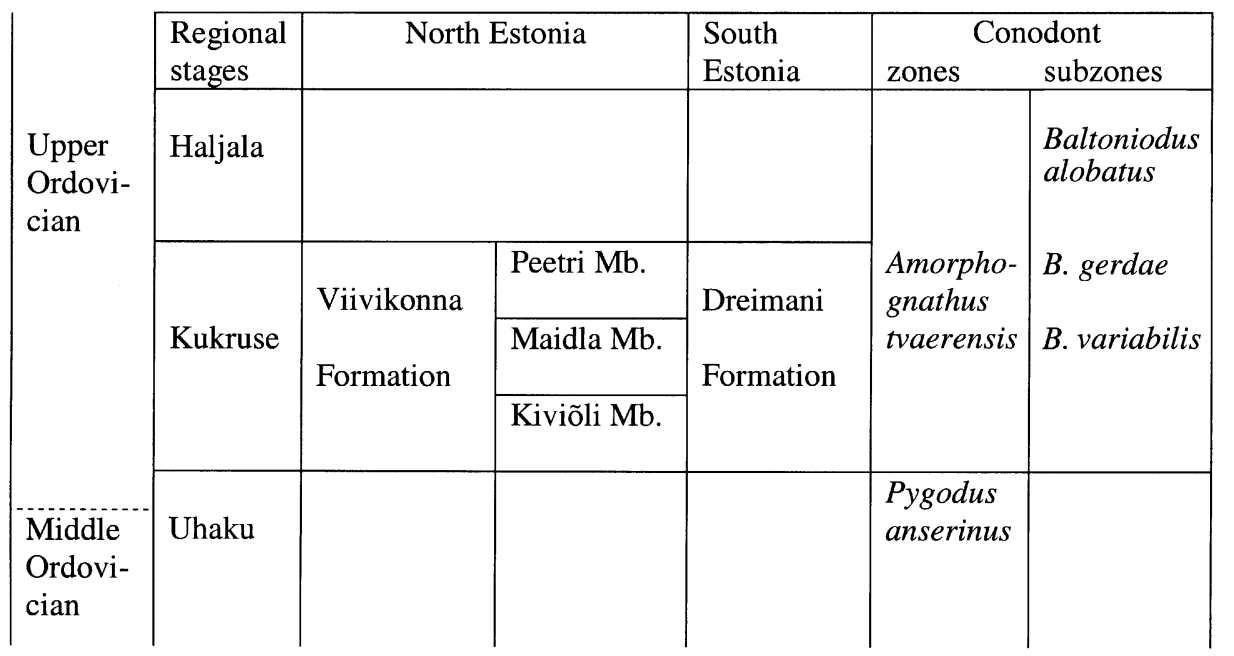

Fig. 2. Stratigraphical scheme with conodont zonation.

B/C, etc. (Kattai et al. 2000). The base of the lowermost commercially important kukersite seam A, at the base of the Viivikonna Formation, also marks the lower boundary of the Kukruse Stage (Hints 1997). The graptolite Orthograptus uplandicus appears approximately at this level (Männil 1984). Männil (1990, p. 17) wrote: "The stage corresponds roughly to the Nemagraptus gracilis Chronozone. In terms of North Atlantic conodont succession the stage seems to correspond to the uppermost part of the Pygodus anserinus Zone, the Prioniodus variabilis (most part of the stage) and to the lowermost Prioniodus gerdae subzones of the Amorphognathus tvaerensis Zone (Männil 1986)". In the chitinozoan biozonation, the Eisenackitina rhenana Subzone of the Laufeldochitina stentor Zone corresponds to the lower part of the Kukruse Stage (Nõlvak \& Grahn 1993; Nõlvak 1997).

We have undertaken a study of conodonts in the Viivikonna Formation with several objectives: to discover if this specific facies harboured an environmentally distinctive conodont fauna; to determine if the collections from different lithologies were dominated by different taxa; and to refine the biostratigraphy of the formation, especially through determination of the position of the base of the Amorphognathus tvaerensis Zone.

The Kohtla section was chosen for its situation in the centre of the oil shale field, near Kohtla-Nõmme (Fig. 1). It exposes the Kiviõli Member, which is the most kukersite-rich and fossiliferous portion of the Viivikonna Formation. A lithologic description of the section was given by Kõrts \& Einasto (1990; see Fig. 3).

Each bed exposed in the section was sampled, with more than one sample being collected from some beds; all lithologic types were included in the sampling. 


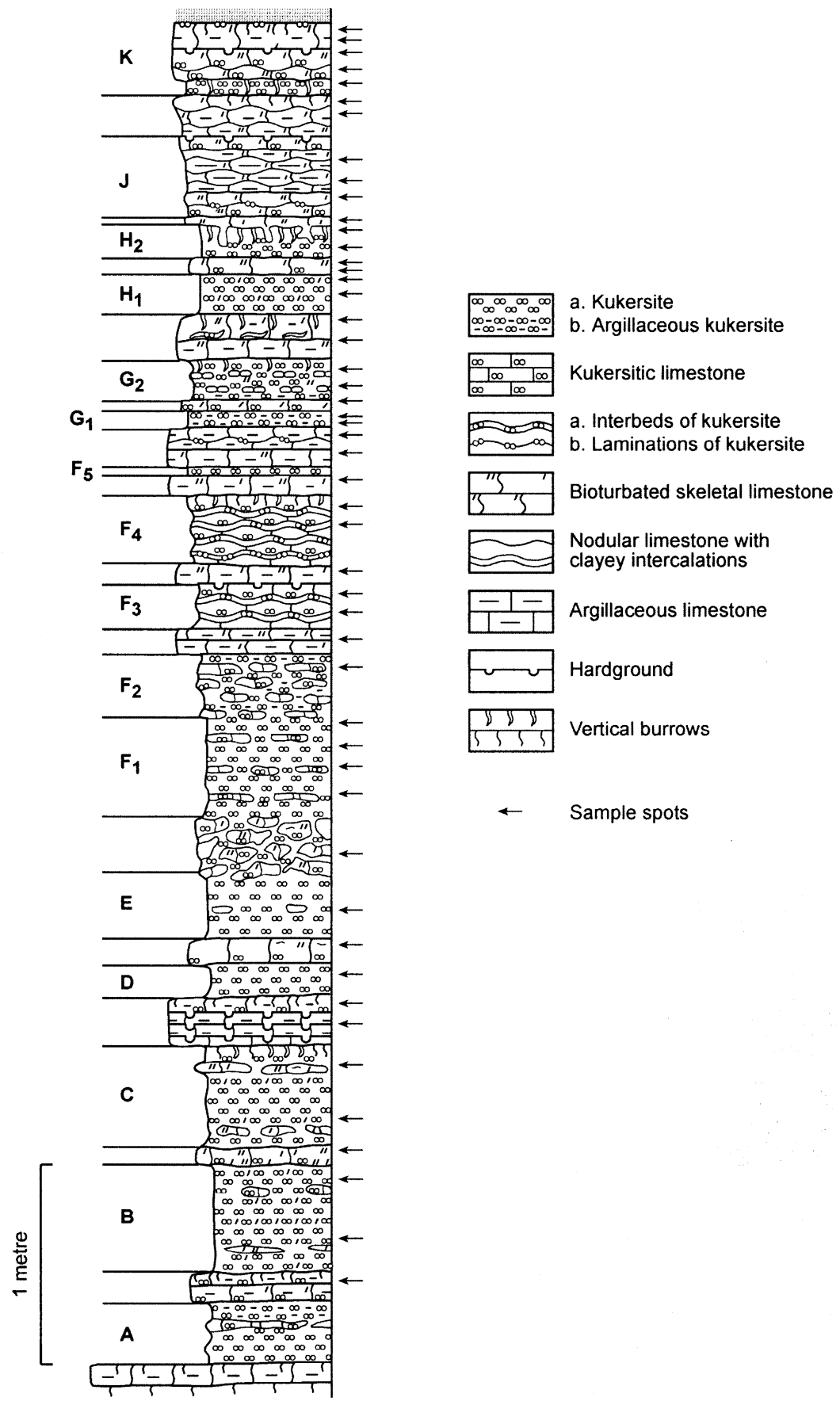

Fig. 3. The Kohtla section of the Kiviõli Member (after Kõrts \& Einasto 1990). Kukersite beds from A to $\mathrm{K}$. 
In all, 49 samples were processed by S.B. and V.V. All limestone samples were dissolved in buffered dilute acetic acid and the residue washed and decanted repeatedly to remove the clay fraction. The kukersite samples were disintegrated by means of sodium hyposulphite, with repeated heating and cooling. The approximate weight of each sample was $1-3 \mathrm{~kg}$. Collections of conodonts are deposited in the Institute of Geology at Tallinn University of Technology. The illustrated specimens form the collection GIT-449.

\section{CONODONTS}

The $6.6 \mathrm{~m}$ of section exposed in the Kohtla-Nõmme abandoned quarry yielded conodonts of the Baltoniodus variabilis Subzone of the Amorphognathus tvaerensis Zone. The conodont elements are generally well preserved with a CAI (conodont colour alteration index) below 1.5. The conodont fauna is similar to that found in coeval sections in other areas, and no taxa endemic to the kukersite facies were recognized. Differences between samples are expressed mainly in numbers of specimens, rather than in differences in taxa or in species dominance (Table 1). The most numerous species is Baltoniodus variabilis, with slightly fewer Semiacontiodus carinatus and Panderodus sulcatus. The zonal species A. tvaerensis is rare in the lower part of the section, but becomes more common from the unit $\mathrm{G}$ upwards. A similar pattern of occurrence of $A$. tvaerensis, with small numbers of specimens early in its range and numerous specimens high up, has been noticed in borehole sections from different parts of Estonia: Taga-Roostoja in the East (Viira \& Männik 1999), Ohesaare in the Southwest (Viira 1967), and the unpublished borehole sections at Are, Seliste, and Viljandi in the South. This suggests that the true first appearance of A.tvaerensis might easily be missed in some sections.

Oslodus semisymmetricus is represented throughout the Kohtla section by rare specimens. Representatives of the genus Drepanoistodus, probably of the species $D$. suberectus and $D$. aff. venustus, are more common. Of particular note is the occurrence in samples $\mathrm{D} / \mathrm{E}-\mathrm{F}_{1}{ }^{3}$ of specimens of Phragmodus polonicus, which was originally described from the Mójcza Limestone of Poland (Dzik 1976, 1994). The biostratigraphic level of P. polonicus was given by Dzik (1976) as the upper E. robustus-lowermost $A$. tvaerensis zones. Two specimens of this species were also recovered from the Kukruse Stage by Bergström (1971), who identified them as Phragmodus n. sp. cf. P. inflexus. Phragmodus n. sp. cf. inflexus (=?P. polonicus Dzik) and Phragmodus sp. (cf. P. polonicus Dzik) have also been reported from the Castell Limestone of the Llandeilian Stage, Wales, in association with A. tvaerensis and Plectodina flexa (Bergström \& Orchard 1985; Bergström et al. 1987). Bergström et al. (1987, p. 307) regarded the Castell Limestone conodont fauna to be of early A. tvaerensis Zone age. 


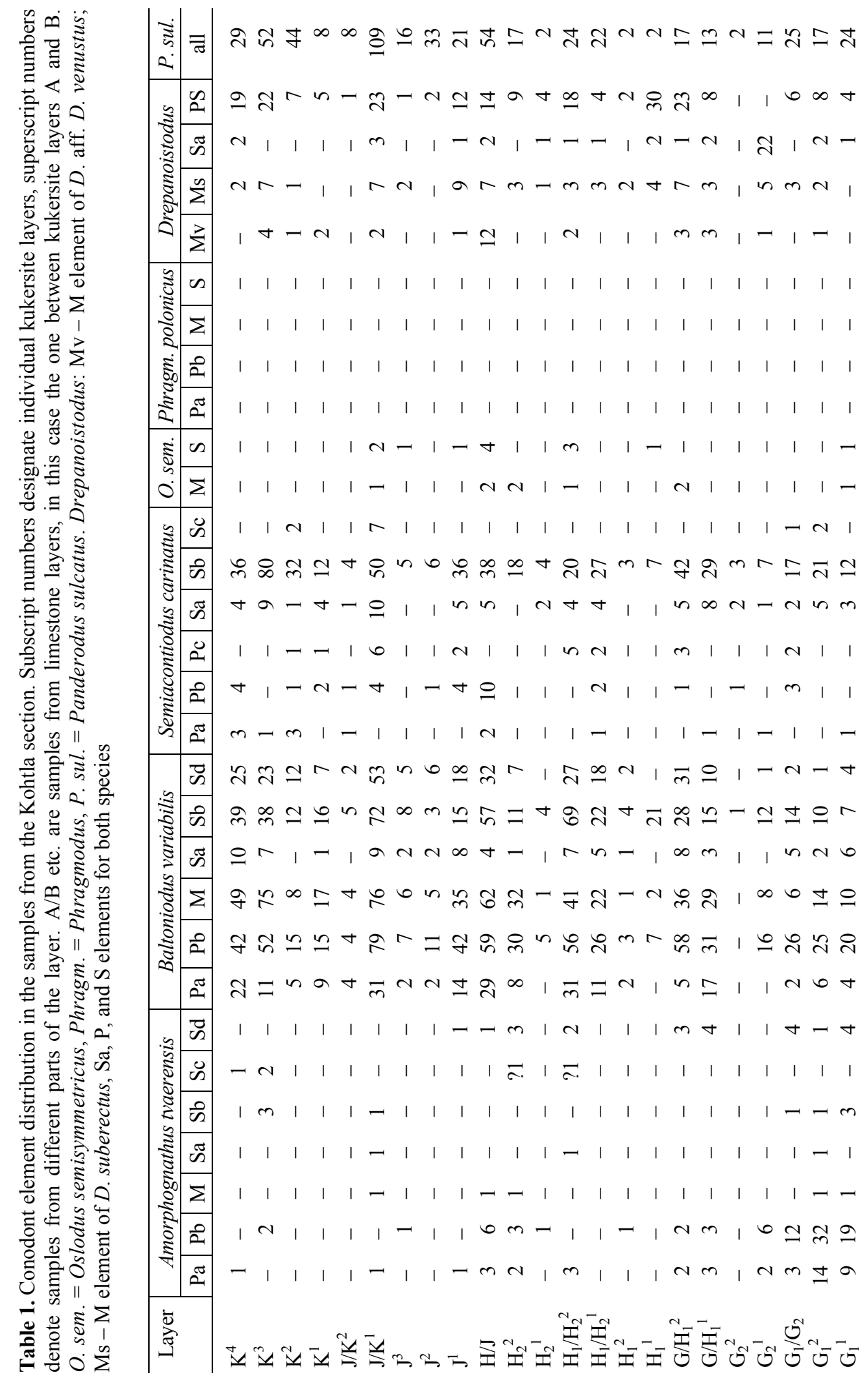




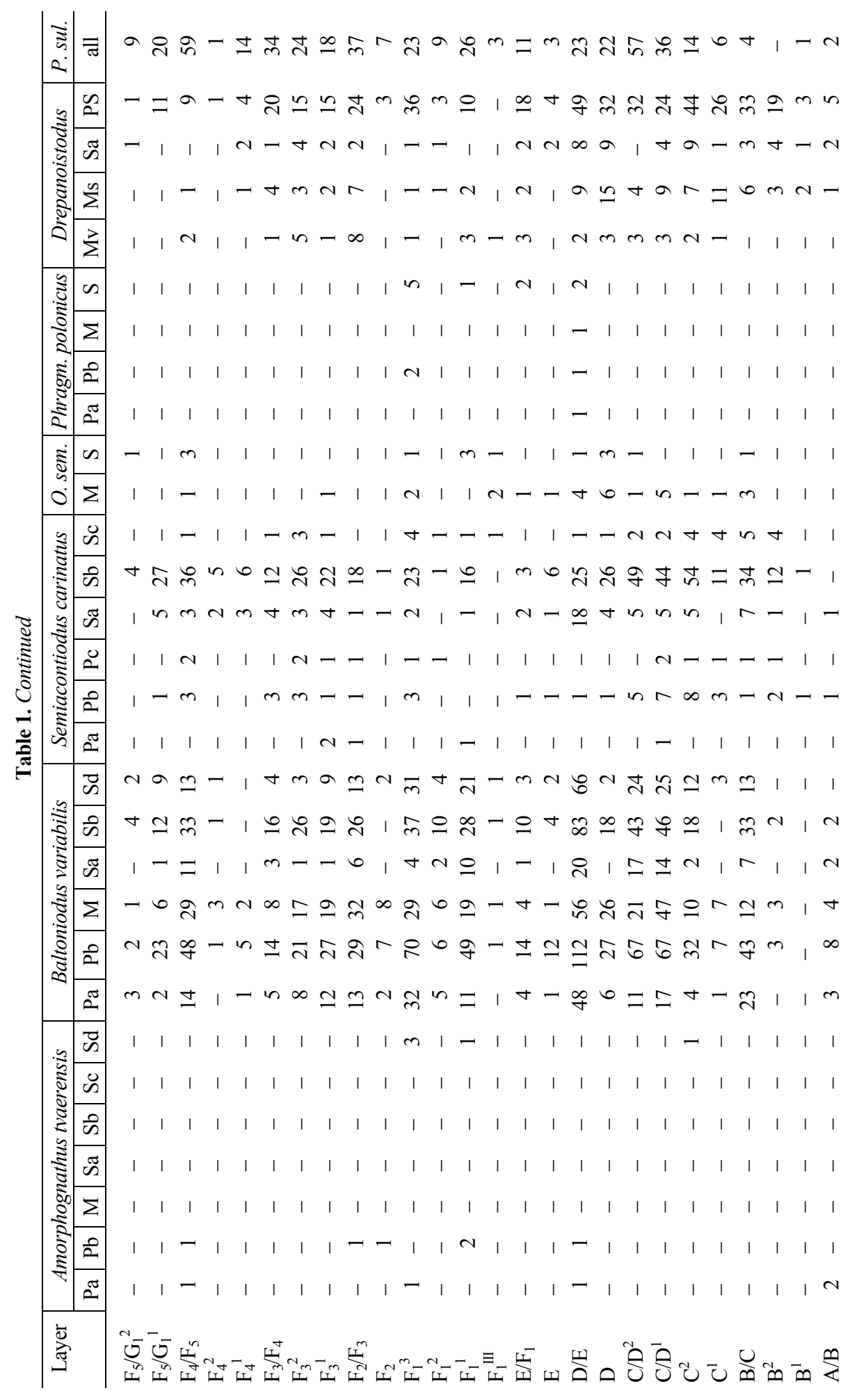




\section{CONODONT BIOZONATION}

There is currently some confusion as to the definition of the base of the Amorphognathus tvaerensis Zone, and also regarding its relationship to the graptolite biozonation and to the base of the Upper Ordovician Series. The base of the zone was originally defined by Bergström (1971, p. 98) unequivocally as being at the first appearance of $A$. tvaerensis. This was later re-iterated by Bergström (1983, fig. 1) in a diagram showing the base of the zone marked by the range base of $A$. tvaerensis, with the range of its putative ancestor, A. inaequalis, defining an upper subzone of the Pygodus anserinus Zone. Dzik (1994), however, regarded $A$. inaequalis to be a junior synonym of $A$. tvaerensis and, therefore, showed $A$.tvaerensis as ranging well down into the $P$. anserinus Zone. Sweet (1988, chart 2) also showed the range of $A$. tvaerensis as extending below the A.tvaerensis Zone, although he separated it from A. inaequalis, which he showed to range through the upper $P$. anserinus Zone and into the lowermost A. tvaerensis Zone. If our identification of the early specimens of $A$. tvaerensis is correct, and if we follow the original definition of the zone, then the occurrence of A. tvaerensis in the lowermost samples of the section (A/B, C, D/E, F) shows that the lower boundary of the A.tvaerensis Zone is likely to be at or below the lower boundary of the Viivikonna Formation and of the Kukruse Stage. This is in contrast to published opinions that the lower boundary of the A. tvaerensis Zone is somewhere within the Kukruse Stage (Bergström 1971; Männil 1986; Nõlvak 1997). However, we must emphasize the difficulty of differentiating A. tvaerensis from A. inaequalis and note the need for more systematic studies of this problem. In South Estonia the first appearance of $A$. tvaerensis is in the upper part of the Dreimani Formation (Põldvere et al. 1998; Männik 2001, 2003).

The base of the Upper Ordovician Series has been formally designated at the base of the Nemagraptus gracilis graptolite Biozone (Bergström et al. 2000). In the stratotype locality at Fågelsång, Sweden, the base of the $P$. anserinus conodont Biozone occurs $3.5 \mathrm{~m}$ below the base of the Upper Ordovician, and conodonts of the upper $P$. anserinus Zone occur in a thin limestone immediately below the Fågelsång Phosphorite, itself $1.5 \mathrm{~m}$ above the boundary (Bergström et al. 2000). Amorphognathus tvaerensis has been found in drill cores a few centimetres above the phosphorite. Bergström et al. (2000) stated that the base of the $N$. gracilis Zone is approximately coeval with the base of the Kukruse Stage, but this correlation is not very precise if, as we suggest, A. tvaerensis ranges from the base of the Kukruse Stage or below. We have found no specimens of $P$. anserinus in our collections from the Kohtla section. It appears, therefore, that the base of the Kukruse Stage is somewhat above the base of the Upper Ordovician. This conclusion contrasts with that of Nõlvak \& Goldman (2004), who suggested that the base of the Upper Ordovician could be traced in the middle of the Kukruse Stage or near the upper boundary.

Baltoniodus variabilis is another important species in the Middle-Upper Ordovician boundary interval and is the eponymous species of the lower subzone of the A. tvaerensis Zone. The first appearance of the species is lower, at the 
base of the upper subzone of the Pygodus anserinus Zone, where it succeeds $B$. prevariabilis (Bergström 1971). As is the case with most species of the genus Baltoniodus, B. variabilis is rather variable with transitional forms that are difficult to assign with confidence to particular species. Dzik (1978, p. 54) noted that primitive specimens of $\mathrm{Pa}$ elements of $B$. variabilis are hardly distinguishable from $P$. alatus ( $=$ Pa element of $B$. prevariabilis) and that their diagnostic shelf (= ledge) varies strongly through ontogeny. Männik (2003) agreed with Dzik's conclusions and noted that the level of appearance of $B$. variabilis in the Ruhnu (500) core section of Estonia is, therefore, quite problematic. Our observations on nine borehole cores through Ordovician sequences show that the replacement of $B$. prevariabilis by $B$. variabilis is clearly transitional and, therefore, does not provide a reliable criterion for resolving boundary problems.

\section{SYSTEMATIC DESCRIPTIONS}

The synonymy lists are condensed, mostly containing only the original citations of species names incorporated in each multielement taxon. In the descriptions, we have used the conventional orientational terms - anterior, posterior, lateral - these do not relate to the anatomical orientation of elements (see Purnell et al. 2000); we have not adopted the biological terminology advocated by Purnell et al. (2000), as there are no natural assemblages known of the taxa we are describing, and we cannot be certain of the anatomical orientations of all of the elements. To designate elements within taxa, we have applied the PMS notation introduced by Sweet \& Schönlaub (1975) and modified by Sweet (1981). As originally devised, this scheme identifies $\mathrm{Pa}, \mathrm{Pb}, \mathrm{M}$, and $\mathrm{Sa}-\mathrm{Sd}$ elements within a conodont apparatus (see Sweet 1988, fig. 2.10); the notation does not relate to actual positions of the various types of elements within the apparatus, but expresses a locational analogy. Where positional homology can be determined, either from natural assemblages or by direct comparison with natural assemblages, an expressly homological notation identifying $\mathrm{P}_{1-4}, \mathrm{M}$, and $\mathrm{S}_{0-4}\left(\mathrm{P}_{\mathrm{n}}-\mathrm{S}_{\mathrm{n}}\right)$ elements can be applied (see Purnell et al. 2000, figs $2,3,5$ ). We are unable to adopt this scheme unequivocally for most of our taxa, so we have generally used the PMS notation as employed by Sweet (1988), but, where we have evidence, we have also attempted to indicate the probable biological position of each element via the notation of Purnell et al. (2000).

\section{Order PRIONIODONTIDA Dzik, 1976}

Remarks. This order, as currently conceived, is paraphyletic (Donoghue et al. 2000, fig. 2). However, pending formal cladistic analysis of phylogenetic relationships within the Conodonta, we use the order here as presented by Sweet (1988).

Naturally occurring apparatuses are known for only a very few prioniodontid taxa. The most fully documented is that of Promissum (Aldridge et al. 1995); this 
apparatus comprises $\mathrm{P}_{1-4}, \mathrm{M}$, and $\mathrm{S}_{0-4}$ elements (Purnell et al. 2000). Four pairs of $\mathrm{P}$ elements have not been reported from other taxa, and it remains open which $\mathrm{P}$ elements of other genera are homologous with those of Promissum. The close similarity between the $\mathrm{P}_{1}$ and $\mathrm{P}_{2}$ elements of Promissum allows three possibilities for homology: (a) just one of these is homologous to the Pa of other apparatuses, or (b) the two are effectively homologous (as serial replicates) to the $\mathrm{Pa}$, or (c) other taxa also have two pairs of $\mathrm{Pa}$ elements. There is strong evidence that the $\mathrm{P}_{3}$ element in Promissum is homologous with the $\mathrm{Pb}$ of other prioniodontid taxa; they are morphologically very similar, sometimes with identical disposition of processes (e.g. in Baltoniodus, Fig. 4). Comparison of elements of Amorphognathus and Baltoniodus with those in natural apparatuses of Promissum shows that a very comparable array of $\mathrm{S}_{0}-\mathrm{S}_{4}$ elements is present in all three taxa. The $\mathrm{M}$ element morphology is not so clearly comparable, but a distinctive $\mathrm{M}$ element is present in Amorphognathus and Baltoniodus.

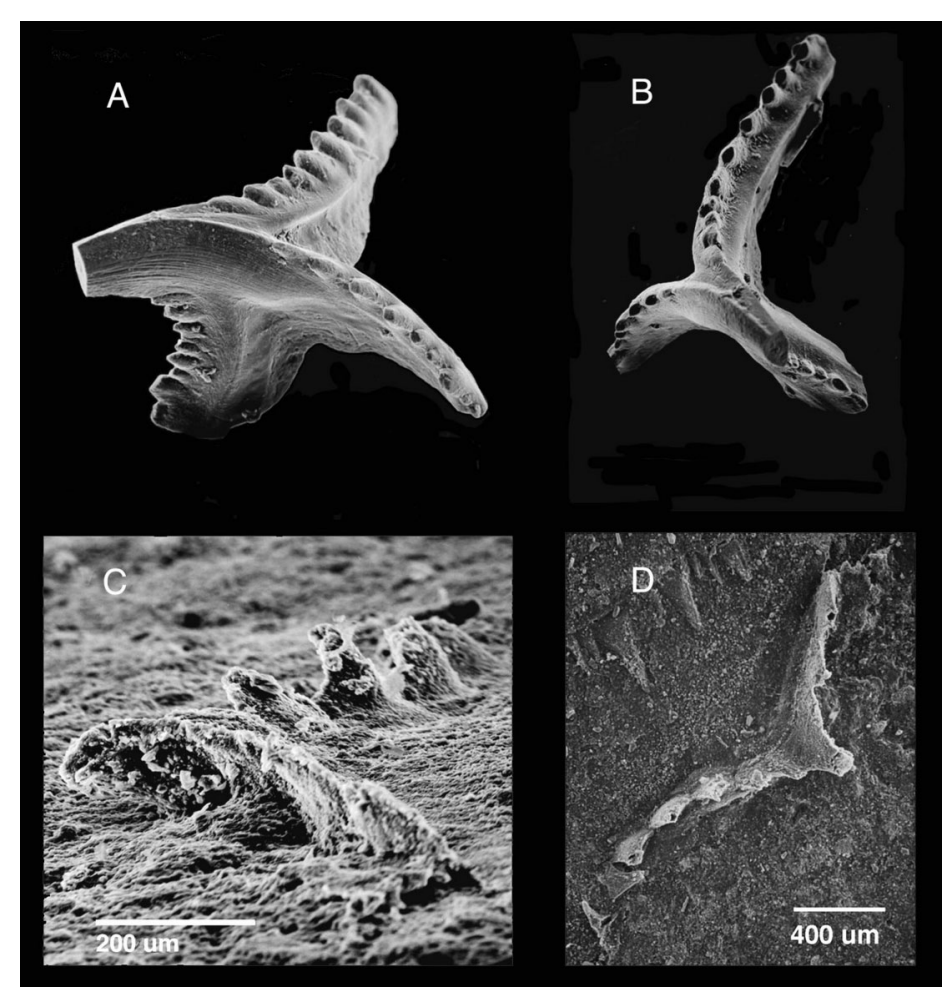

Fig. 4. Comparison of process orientation in specimens of the $\mathrm{Pb}$ element of Baltoniodus variabilis and $\mathrm{P}_{3}$ elements of Promissum pulchrum. $\mathrm{A}, \mathrm{B}$, dextral $\mathrm{Pb}$ element of $B$. variabilis from the Suhkrumägi section, Tallinn, Estonia, specimen 246; A, lateral view, with the concave margin of the cusp directed towards the left of the image, $\times 55$; B, oral view, with the cusp directed towards the bottom right of the image, $\times 55$. C, D, cast of the $\mathrm{P}_{3}$ element in P. pulchrum specimen $\mathrm{C} 488$, Soom Shale, Keurbos, Clanwilliam, South Africa, in comparable views and orientation. 
Family BALOGNATHIDAE Hass, 1959

Genus Amorphognathus Branson \& Mehl, 1933

Remarks. In complicated prioniodontid platform elements, like the $\mathrm{Pa}$ of Amorphognathus, there is often a difficulty in determining which processes are homologous with those of elements in other taxa with fewer processes. This can probably only be established by sectioning of specimens near the apex of the basal cavity (see below for Baltoniodus). Here we use conventional terminology for Amorphognathus $\mathrm{P}$ elements, while recognizing that processes described as posterior and lateral may not be homologous with those described as posterior and lateral for Baltoniodus.

Amorphognathus tvaerensis Bergström, 1962

Plate I, figures 1-9, 11, 13-15

1962 Ambalodus triangularis Branson \& Mehl ssp. erraticus n. ssp.; Bergström, pp. 26, 27, pl. 3, figs 15-17.

1962 Ambalodus triangularis Branson \& Mehl ssp. suecicus n. ssp.; Bergström, pp. 28, 29, pl. 3, figs 11-14.

1962 Amorphognathus tvaerensis n. sp.; Bergström, pp. 36, 37, pl. 4, figs 7-10.

1962 Amorphognathus ordovicica Branson \& Mehl ssp. simplicior; Bergström, pp. 34, 35, pl. 4, figs 2, 5, 6 .

1962 Amorphognathus ordovicica Branson \& Mehl spp. simplicior n. ssp. var.?; Bergström, p. 35, pl. 4, figs 1, 3, 4 .

1962 Ligonodina elongata Rhodes, 1953; Bergström, pp. 43, 44, pl. 5, figs 14, $15,17,18$.

1962 Roundya inclinata (Rhodes, 1953); Bergström, pp. 53, 54, pl. 5, figs 10-13.

1962 Tvaerenognathus ordovicica n. sp.; Bergström, pp. 57, 58, pl. 1, figs 1-5; text-fig. $2 \mathrm{~F}$.

Remarks. The holotype of $A$. tvaerensis is a dextral $\mathrm{Pa}$ (amorphognathiform) element (Bergström 1962, pl. 4, figs 7-10). An apparatus reconstruction was given by Bergström (1971) and has been considered to include amorphognathiform $\mathrm{Pa}$, ambalodiform $\mathrm{Pb}$, holodontiform $\mathrm{M}$, hibbardelliform $\mathrm{Sa}$, ligonodiniform $\mathrm{Sb}$, and tetraprioniodiform Sd elements. The Pa element is most important for species identification. The $\mathrm{Sa}$ and $\mathrm{Sd}$ elements are similar to the corresponding elements of species of Baltoniodus, but may be distinguished by minor differences and by their generally smaller size.

Description. The amorphognathiform Pa element is represented mostly by broken specimens, with the laterally compressed anterior process commonly separated from the flat posterior part. The anterior process is blade-like, with fused high uneven denticles and with a ledge on the aboral margin. The anterior end of the 


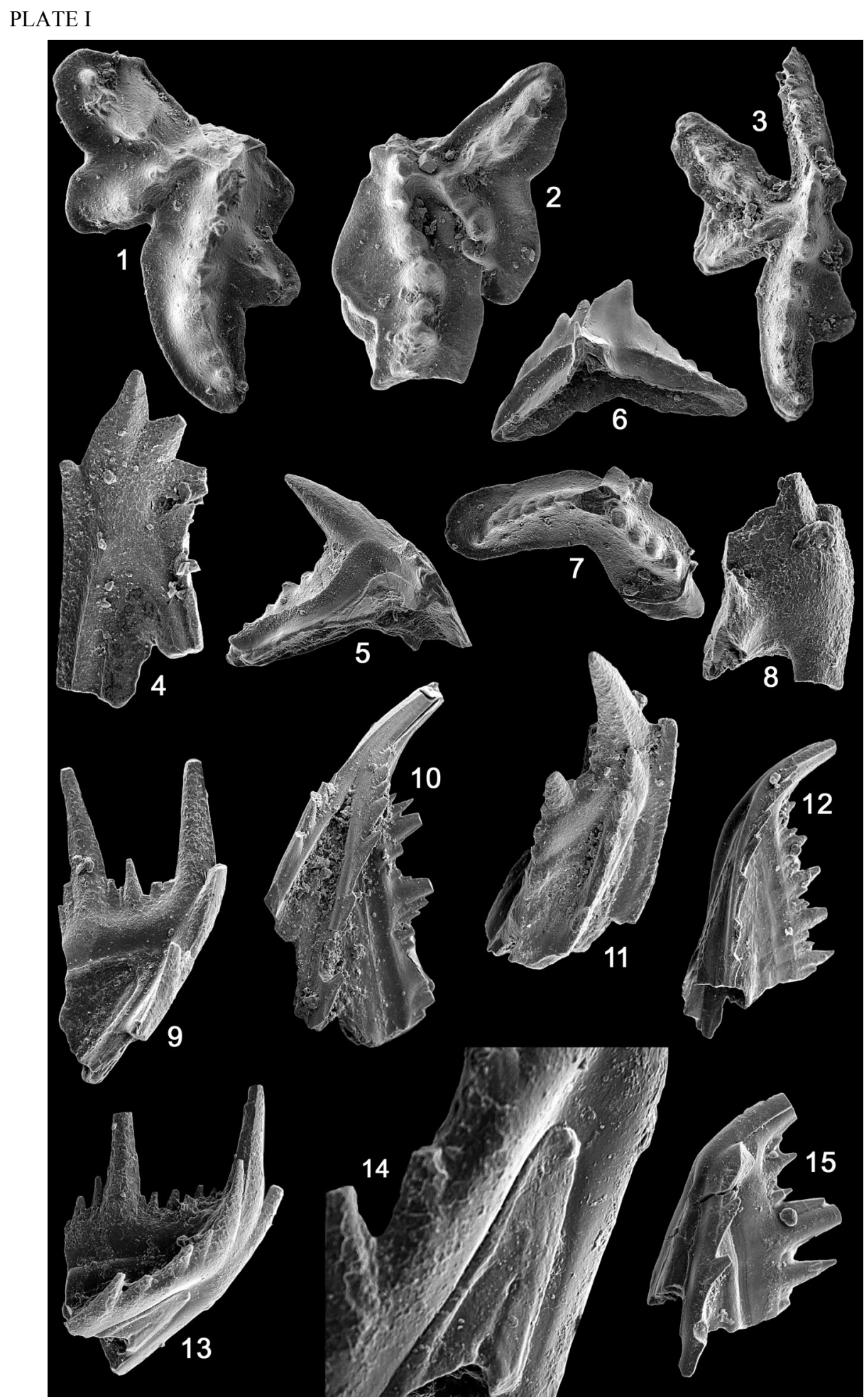


blade may be directed downwards. The most proximal denticle of the anterior process is usually the widest and displays a costa on one side. This costa is the origination of the antero-lateral process, which in our material is not preserved. The anterior process on all specimens retains the basal body. The posterior part of the Pa element is flat, broad, and stout. The denticles on the posterior and lateral processes are low, thick, even node-like. The ledge around the processes is conspicuous and may form a vertical border on the margins of processes. In oral view the posterior process of the dextral specimens is more curved and sigmoidal. The second posterior lateral process is more strongly developed on dextral specimens (Pl. I, figs 1, 3). The sinistral element shows widening but lacks denticles or nodes (Pl. I, fig. 2). The Kohtla specimens of the Pa element in general agree well with the original description of Amorphognathus tvaerensis given by Bergström (1962).

The ambalodiform $\mathrm{Pb}$ element displays clear differences between dextral and sinistral specimens. The cusp of dextral specimens is higher and the anterior and posterior processes form a smaller angle (approximately $90^{\circ}$ ) with each other. The anterior process is the longest, the lateral process is short, compressed, and often broken. The cusp of sinistral specimens is small but distinct and always bigger than denticles of the anterior process. All specimens of the Pb element show a conspicuous ledge along the anterior and posterior processes. Most specimens have retained the basal body. The dextral and sinistral specimens of the $\mathrm{Pb}$ element are similar to those described originally by Bergström (1962) as Ambalodus triangularis suecicus and A. triangularis erraticus.

The holodontiform $\mathrm{M}$ element is represented by only a few specimens. On the anterior process they have weakly developed denticulation, with only one denticle distinguishable. The cusp and the denticles of the posterior process form a united row of large denticles, with the anteriormost vertical and the posteriormost directed posteriorly. The lateral process has 1-2 relatively large vertical denticles.

The $\mathrm{M}$ and ramiform $\mathrm{S}$ elements are small and relatively rare in our collection.

\section{Explanation of Plate I}

Figs 1-9, 11, 13-15. Amorphognathus tvaerensis Bergström. 1-3, oral views, Pa element, 449-1, 449-2, 449-3; 1, 2, sample $\mathrm{G}_{1}, 3$, sample $\mathrm{G}_{1} / \mathrm{G}_{2} ; 1, \times 80,2,3, \times 100.4$, 8, lateral and posterio-lateral views, $M$ element, 449-4, 449-5; 4, sample $\mathrm{G}_{1}{ }^{2}, \times 150,8$, sample $\mathrm{G}_{1}, \times 200.5$, 6, lateral views, $\mathrm{Pb}$ element, 449-6, 449-7; 5, sample $\mathrm{G}_{1}{ }^{2}, \times 120,6$, sample $\mathrm{F}_{1}{ }^{1}, \times 120.7$, oral view, $\mathrm{Pb}$ element, 449-8; sample D/E, $\times 120$. 9, lateral view, Sc element, 449-9; sample $\mathrm{K}^{3}, \times 150$. 11, lateral view, Sd element, 449-10; sample $\mathrm{G}_{1}{ }^{2}, \times 150.13,14$, lateral view and close-up to show basal filling, Sa element, 449-11; sample top, $\times 150, \times 500$. 15, lateral view, Sa element, 449-12; sample $\mathrm{H}_{1} / \mathrm{H}_{2}, \times 150$.

Figs 10, 12. Baltoniodus variabilis (Bergström). 10, lateral view, $\mathrm{Sd}$ element, 449-13; sample $\mathrm{H}_{2}^{2}$, $\times 150$. 12, lateral view, Sa element, 449-14; sample G1/G2, $\times 100$. 
Remarks. Conventionally, identification of processes relies on locating where the process joins the cusp (Sweet 1981). Within P elements of Baltoniodus, the "posterior" process is clear, aligned with the concave margin of the cusp, but the "lateral" and "anterior" processes both arise from the anterior margin. Sectioning through the apical portion of the basal cavity (Fig. 5) has revealed that the lateral process has a clear junction with the main axis that is initially formed by the anterior and posterior processes during the early juvenile stages of growth, and hence can be reliably distinguished.

The apparatus of Baltoniodus has two types of pastinate $\mathrm{P}$ element, usually termed $\mathrm{Pa}$ and $\mathrm{Pb}$, and has commonly been reconstructed, through reference to the ozarkodinid apparatus plan, as having just two P element pairs (e.g. Sweet 1988). This conclusion needs reconsideration in the light of evidence regarding the architecture of prioniodontid apparatuses. The Pa element compares morphologically to both the $\mathrm{P}_{1}$ and $\mathrm{P}_{2}$ elements of the apparatus of Promissum, and it is possible that the $\mathrm{Pa}$ element of Baltoniodus occupied two positions within its apparatus. However, undescribed prioniodontid apparatuses from the same locality as Promissum (the Soom Shale, Upper Ordovician, South Africa) contain only one P element of Pa morphology and this may also be the case with Baltoniodus. These new apparatuses confirm earlier predictions that some prioniodontid apparatuses possessed three $\mathrm{P}$ elements $(\mathrm{Pa}, \mathrm{Pb}$, and $\mathrm{Pc})$, each with a distinctive morphology (Männik \& Aldridge 1989; Aldridge et al. 1995), and might indicate

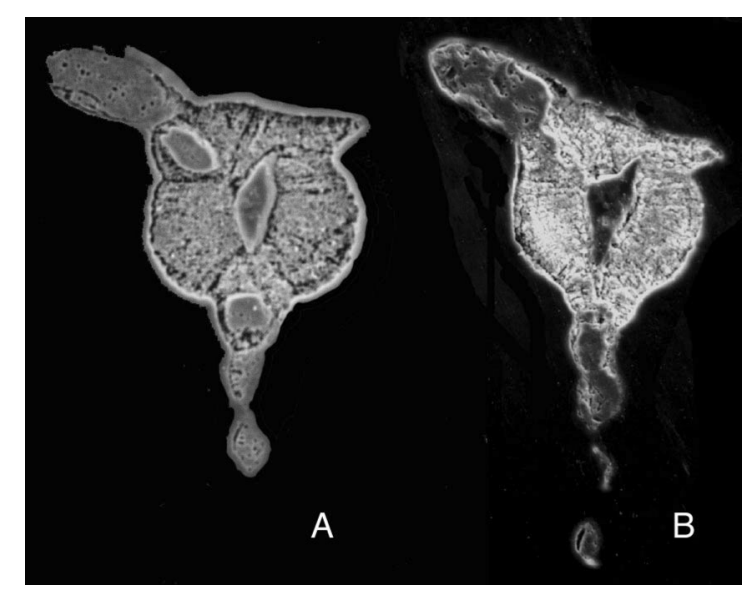

Fig. 5. Sections through the apex of the basal body of a specimen of the Pa element of Baltoniodus variabilis to show the development of processes. A, section $100 \mu \mathrm{m}$ from the apex, showing the line of the posterior and anterior processes. B, section $200 \mu \mathrm{m}$ from the apex, showing the beginning of development of the lateral process at about 90 degrees from the anterior-posterior line. The posterior process points to the bottom of illustrations. 
that we should be searching for a third, distinctive element in Baltoniodus. The $\mathrm{Pb}$ element has anterior and lateral processes that show the same angular disposition around the cusp as the $\mathrm{P}_{3}$ element of Promissum, implying that the two are homologous (Fig. 4). No element has been identified for Baltoniodus that is morphologically comparable to the Promissum $\mathrm{P}_{4}$ element. However, counts of $\mathrm{Pb}$ elements in the Kohtla samples consistently outnumber the $\mathrm{Pa}$ elements (1183 against 375 , a ratio of $3.2: 1$ ); a similar overrepresentation of $\mathrm{Pb}$ elements (at about $2: 1$ ) occurs in our collections of $B$. variabilis from Suhkrumägi, Estonia. Thus, it is possible that $\mathrm{Pb}$ elements of Baltoniodus occupied $\mathrm{P}_{2}+\mathrm{P}_{3}, \mathrm{P}_{3}+\mathrm{P}_{4}$, or even $\mathrm{P}_{2}+\mathrm{P}_{3}+\mathrm{P}_{4}$ positions. Resolution of the number and homologies of $\mathrm{P}$ elements probably awaits the discovery of a natural assemblage of Baltoniodus.

Baltoniodus variabilis (Bergström, 1962)

Plate I, figures 10, 12; Plate II, figures 1-12; Plate III, figures 1-9

1962 Prioniodus variabilis n. sp.; Bergström, p. 51, pl. 2, figs 1-7.

1962 Oistodus robustus n. sp.; Bergström, p. 45, pl. 3, figs 7-10, text-fig. 3F.

1962 Paracordylodus lindstroemi n. sp.; Bergström, pp. 50, 51, pl. 2, figs 8-12, text-fig. 2C.

1962 Tetraprioniodus asymmetricus n. sp.; Bergström, pp. 55, 56, pl. 2, figs 15-17.

Remarks. The holotype of Baltoniodus variabilis is a $\mathrm{Pb}$ element and was described in detail by Bergström (1962), as were other elements except the Pa element. Bergström (1971, p. 148) stated that specimens of the Pa (amorphognathiform) elements "are similar to that of Prioniodus prevariabilis, except that they have conspicuous ledges along the processes and a prominent triangular lateral expansion of the inner side of the posterior process". The Pa element of B. prevariabilis, the apparatus of which was also established by Bergström (1971), was given as Prioniodus alatus Hadding, 1913.

Description. The Pa element with an erect cusp, much smaller than that of the $\mathrm{Pb}$ element. At mid-height of the cusp the lateral process is initiated as a carina and becomes anteriorly directed, with a denticulated oral edge (Pl. II, figs 10, 11). The diagnostic triangular lateral expansion of the inner side of the posterior process is often broken ( $\mathrm{Pl}$. II, figs 6, 8, 12); where preserved this expansion may be quite broad but thin and easily damaged (Pl. II, fig. 10, where the posterior part of the expansion is broken away). The outer side of the posterior process and both sides of the lateral process generally have ledges. Denticulation is more regular on the lateral process which has slender fused denticles. The anterior process curves sharply from the line of the posterior process and bears a few small denticles, the process is often broken distally. The $\mathrm{Pb}$ element with a large erect cusp. The anterior edge of the cusp is sharp and flexes sharply laterally to continue as a denticulate anterior process. The posterior process has small denticles and 
widens aborally. The lateral process is the longest, bearing fused denticles. The posterior and lateral processes have ledges below the denticle rows. The basal edges of the processes are very thin and fragile.

The $\mathrm{M}$ element has a stout recurved cusp and a large basal portion. The Sa, $\mathrm{Sb}$, and Sd elements have irregularly alternating denticulation on their posterior processes and a basal funnel is usually preserved. The Kohtla specimens of $\mathrm{Pb}$, $\mathrm{M}, \mathrm{Sa}, \mathrm{Sb}$, and $\mathrm{Sd}$ elements compare well with the original descriptions given by Bergström (1962).

Family CYRTONIODONTIDAE Hass, 1959

Genus Phragmodus Branson \& Mehl, 1933

Remarks. A preliminary study of natural assemblages of Phragmodus inflexus by Repetski et al. (1998) has shown that the apparatus of this genus was very similar to that of ozarkodinids, with two pairs of P elements. Purnell et al. (2000), therefore, suggested that the $\mathrm{P}_{\mathrm{n}}-\mathrm{S}_{\mathrm{n}}$ notation could be applied without equivocation. The possession of just two pairs of $\mathrm{P}$ elements distinguishes this genus from those of the Balognathidae, which have three or four pairs of $\mathrm{P}$ elements.

Phragmodus polonicus Dzik, 1978

Plate III, figures $10-17$

1978 Phragmodus polonicus sp. n.; Dzik, pp. 63, 64, pl. 14, figs 1-4, textfig. 5a-d (non e).

Description. The $\mathrm{P}_{1}$ element has a short cusp that is almost twice as wide as the denticles on the lateral and posterior processes. The cusp axis is at $90^{\circ}$ to the posterior process and approximately $100 / 110^{\circ}$ to the lateral process when viewed laterally. The anterior edge of the cusp extends into an adenticulate anterior process which curves away to the side. The lateral process bears large regularly sized denticles, separated by broad v-shaped spaces. The posterior process has slightly shorter and more rounded denticles than those of the lateral process. When viewed from both above and laterally, the posterior and lateral processes form a straight line.

\section{Explanation of Plate II}

Figs 1-12. Baltoniodus variabilis (Bergström). 1-5, 9, lateral views, Pb element, 449-15-449-20; 1, 2, sample $\mathrm{C} / \mathrm{D}^{1}, 3,4$, sample $\mathrm{G} / \mathrm{H}^{1}$, 5, sample $\mathrm{H} / \mathrm{J}$, 9, sample top; $1,3,5, \times 100,2,9, \times 120,4$, $\times 80$. 6-8, 12, lateral views, Pa element, 449-21-449-24; 6, sample top, 7, 12, sample $\mathrm{C} / \mathrm{D}^{1}$, 8 , sample H/J; $6, \times 80,7, \times 100,8,12, \times 120.10,11$, oral-anterior view and anterior detail of $10, \mathrm{~Pa}$ element, 449-25; sample G/ $\mathrm{H}^{2}, \times 120, \times 700$. 
PLATE II

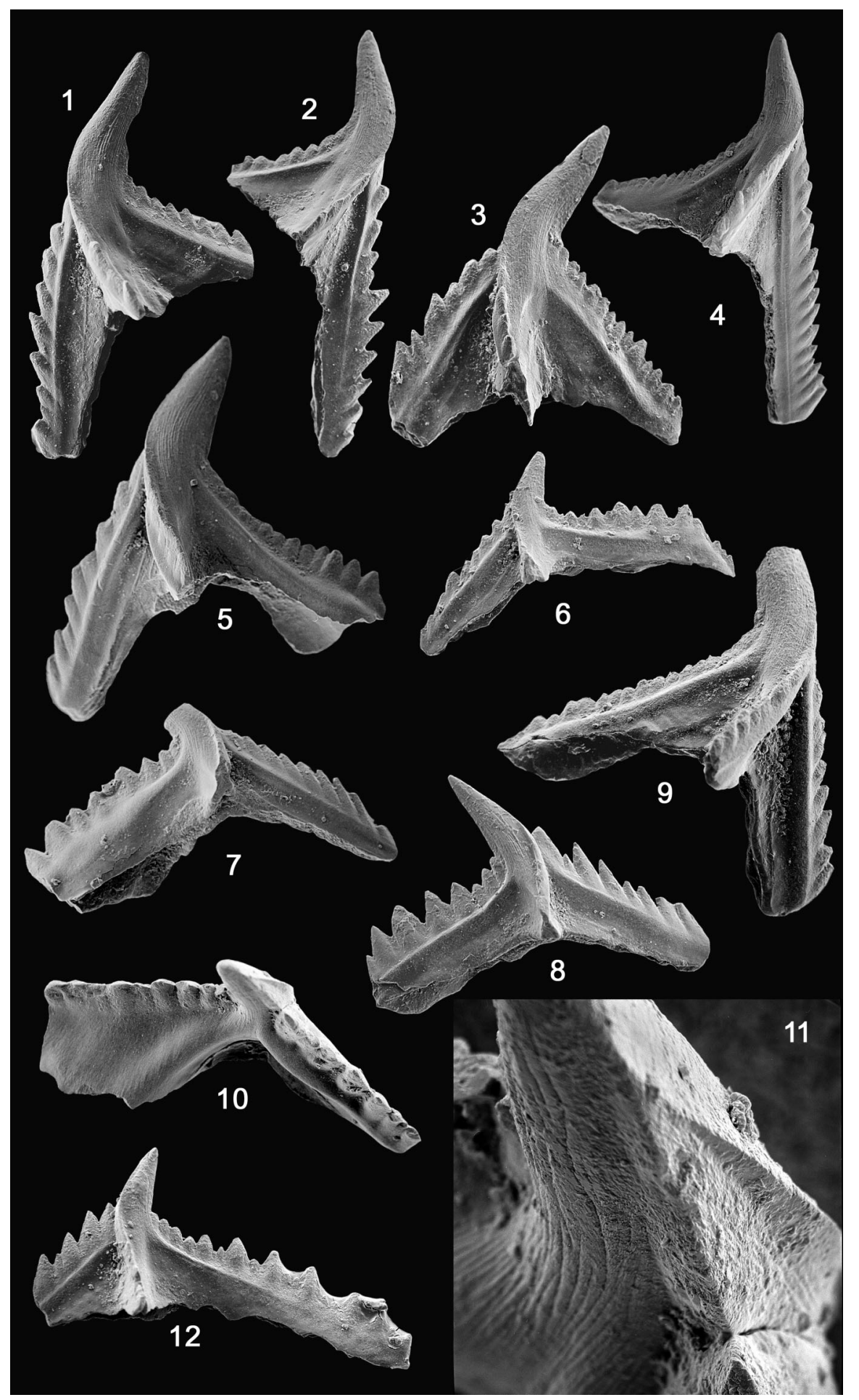




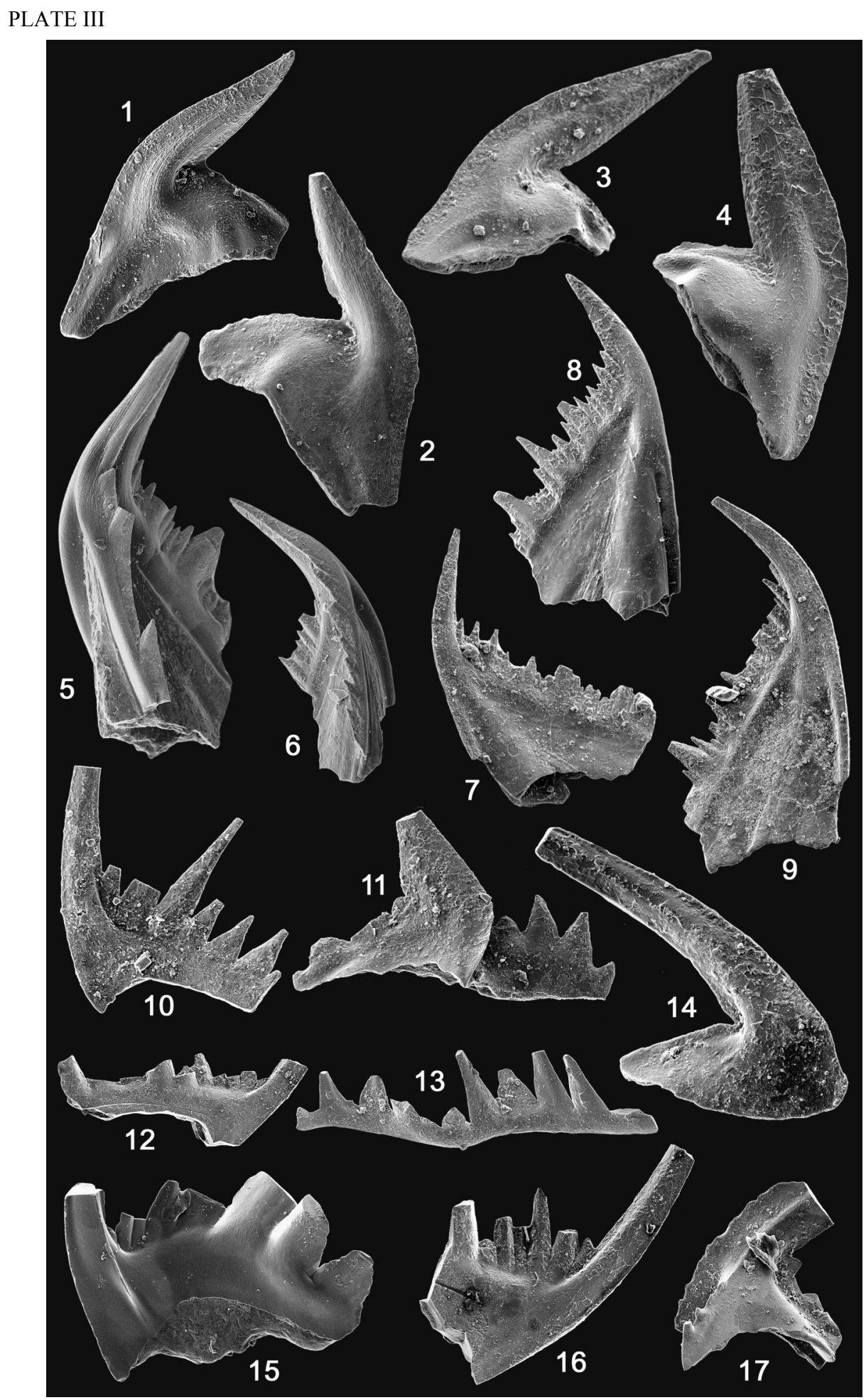


The $\mathrm{P}_{2}$ element is quite robust, with a broad cusp directed at right angles to the posterior process. The anterior process is continuous from the anterior edge of the cusp and is weakly denticulated. The lateral process originated as a carina on the cusp and is directed aborally; it has small denticles that are slightly inclined anteriorly.

The M element has a reclined tall cusp, which leans over a posteriorly extended base. The antero-aboral angle is slightly rounded and the aboral margin is gently convex.

The $\mathrm{S}$ elements display considerable variation, but all have a tall distinct, gently tapering cusp and a denticulated posterior process. The $\mathrm{S}_{0}$ element has a lateral carina on each side of the cusp; these almost reach the aboral margin. The posterior process is gently arched for approximately the first third of its length. The denticles on the posterior process are very high and wide in the central part of the process, where they may become almost twice as tall and wide as the cusp. The posterior processes of the other S elements are very long and have almost even-sized denticles; they show a zigzag pattern in oral view.

Order BELODELLIDA Sweet, 1988

Family DAPSILODONTIDAE Sweet, 1988

Genus Oslodus Zhang, 1998

Oslodus semisymmetricus (Hamar, 1966)

Plate IV, figures 15-20

1966 Acontiodus semisymmetricus n. sp.; Hamar, p. 51, pl. 7, figs 5, 6, textfig. 3:6.

1966 Oistodus breviconus Branson \& Mehl, 1933; Hamar, p. 63, pl. 1, fig. 19, text-fig. 4, no. 11.

1974 Acontiodus sp. n.; Viira, p. 50, pl. 12, figs 16, 17, text-fig. 35.

1974 Oistodus sp. n. B; Viira, p. 97, pl. 11, figs 13, 14, text-fig. 117.

1976 Paltodus? semisymmetricus (Hamar); Dzik, p. 435, text-fig. 18b-f.

1983 Besselodus semisymmetricus (Hamar); Dzik, text-fig. 4:7.

\section{Explanation of Plate III}

Figs 1-9. Baltoniodus variabilis (Bergström), lateral views. 1-4, M element, 449-26-449-29; 1, 2, sample $\mathrm{C} / \mathrm{D}^{1}, 3,4$, sample $\mathrm{K}^{4} ; 1,2,4, \times 150,3, \times 120$. 5, 6, Sa element, 449-30, 449-31; 5 , sample $\mathrm{G} / \mathrm{H}^{1}, \times 120,6$, sample $\mathrm{F}_{1}{ }^{3}, \times 100$. 7-9, Sc element, 449-32-449-34; 7, 8, sample $\mathrm{F}_{1}{ }^{3}$, 9, G/H low; 7, 8, ×100, 9, ×120.

Figs 10-17. Phragmodus polonicus Dzik, lateral views. 10, Sb element, 449-35; sample D/E, $\times 200$. 11, Pa element, 449-36; sample D/E, $\times 200.12,16$, Sc element, 449-37, 449-38; sample $\mathrm{F}_{1}{ }^{3}, \times 90$, $\times 120$. 13, fragment of $\mathrm{S}$ posterior process, 449-39; sample $\mathrm{F}_{1}{ }^{3}, \times 120.14$, $\mathrm{M}$ element, 449-40; sample $\mathrm{D} / \mathrm{E}, \times 250$. 15, Sa element, 449-41; sample E/F, $\times 150$. 17, Pb element, 449-42; sample D/E, $\times 120$. 


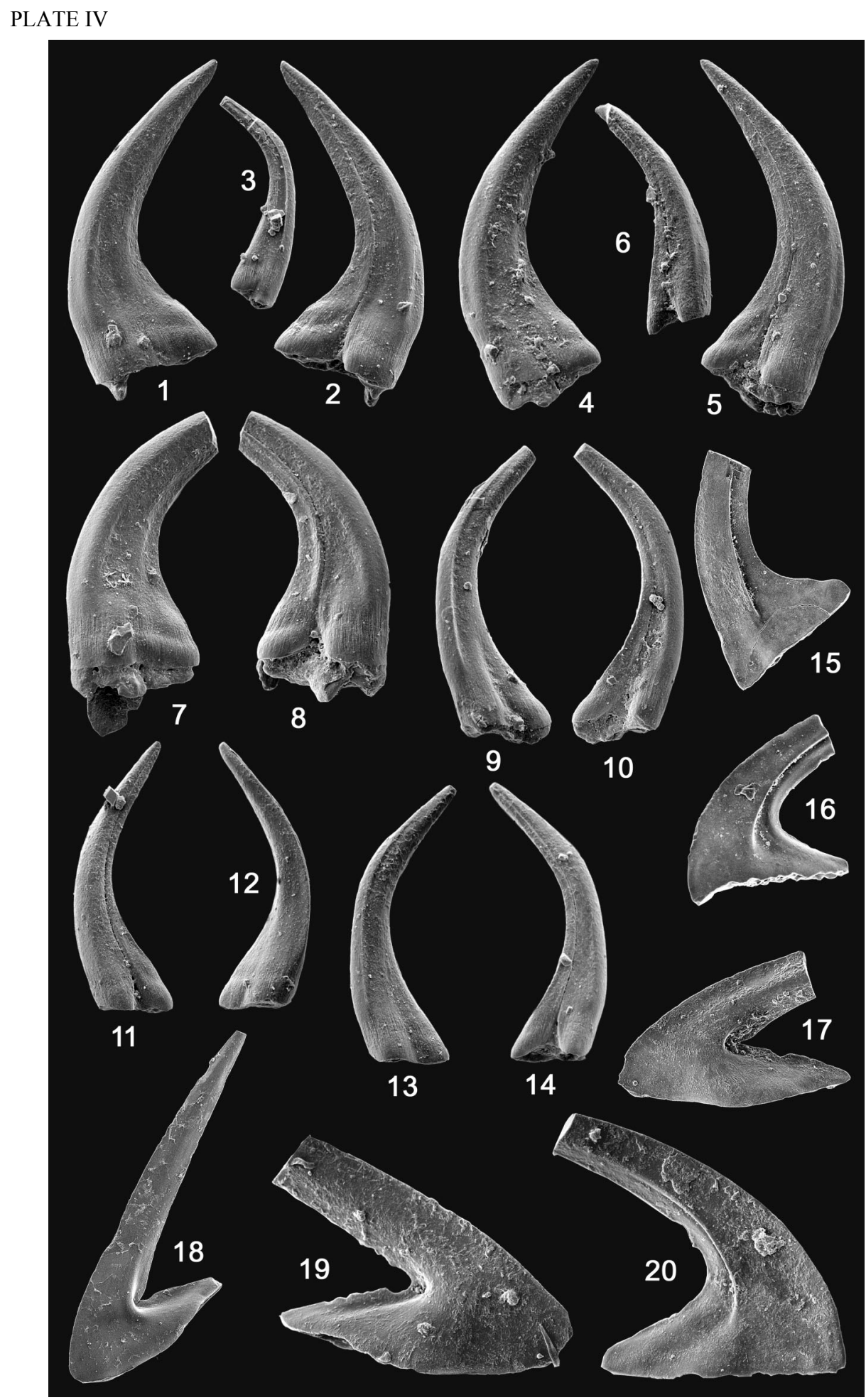


1994 Paltodus? semisymmetricus (Hamar); Dzik, p. 76, pl. 16, figs 14, 15, textfig. $12 \mathrm{~d}$.

1998 Oslodus semisymmetricus (Hamar); Zhang, pp. 77, 78, pl. 12, figs 14-20.

2000 Besselodus semisymmetricus (Hamar, 1966); Leslie, pp. 1129-1131, figs 3.15-3.19.

Remarks. Dzik (1976) included four form species in this multielement species, but no detailed description was given. Zhang (1998) identified P, M, and four S elements. Leslie (2000) differentiated three types of elements: geniculate (oistodiform) and two varieties of costate coniform (acontiodiform and distacodiform). In our material we recognized specimens of two types, $\mathrm{M}$ and $\mathrm{S}$ elements; the latter are acontiodiform, with one posteriorly situated costa on each side.

\section{Order PROTOPANDERODONTIDA Sweet, 1988 \\ Family DREPANOISTODONTIDAE Fåhraeus \& Nowlan, 1978}

Genus Drepanoistodus Lindström, 1971

Remarks. Specimens of Drepanoistodus occur throughout the Kohtla section, but not all elements can be confidently assigned to a species; both Drepanoistodus suberectus (Branson \& Mehl, 1933) and Drepanoistodus aff. D. venustus Stauffer, 1935 are represented. The $\mathrm{M}$ element is distinctive, and we only distinguished this in our species counts (Fig. 3, Table 1); Sa elements were also counted as a separate morphological group but all other Drepanoistodus $\mathrm{S}$ and $\mathrm{P}$ elements were counted together.

The oistodontiform M element of D. suberectus is geniculate (Fig. 6), with a rounded anterio-basal corner and rounded basal margin. The low base has widely expanded lateral surfaces. The tip of the low basal cavity is weakly expressed, but always points towards the anterior edge. The cusp is straight, gently tapering. The outer side of the cusp is smoothly convex, the inner side is usually provided with a faint costa. The edges of the cusp are very sharp, with rather wide flat margins that may easily be broken.

The oistodontiform M element of $D$. aff. D. venustus has an anterio-posteriorly extended base, so that the cusp is only a little longer (Fig. 6). The angle between

\section{Explanation of Plate IV}

Figs 1-14. Panderodus sulcatus (Fåhraeus), lateral views. 1, 2, 4, 5, falciform element, 449-43449-46; sample $\mathrm{J} / \mathrm{K}^{1}, \times 120.3$, graciliform element, 449-47; sample $\mathrm{G}_{1} / \mathrm{G}_{2}, \times 120$. 6, ?arcuatiform element, 449-48; sample $\mathrm{J} / \mathrm{K}^{1}, \times 120$. 7, 8, falciform element, 449-49, 449-50; sample $\mathrm{J} / \mathrm{K}^{1}, \times 120$. 9,10 , arcuatiform element, 449-51, 449-52; sample $\mathrm{J} / \mathrm{K}^{1}, \times 120.11,12$, tortiform element, 449-53, 449-54; sample $\mathrm{J} / \mathrm{K}^{1}, \times 120$. 13, 14, arcuatiform element, 449-55, 449-56; sample $\mathrm{J} / \mathrm{K}^{1}, \times 120$.

Figs 15-20. Oslodus semisymmetricus (Hamar), lateral views. 15, 16, S element, 449-57, 449-58; sample $\mathrm{D}, \times 150, \times 150.17$, M element, 449-59; sample $\mathrm{D}, \times 150$. 18, M element, 449-60; sample $\mathrm{B} / \mathrm{C}, \times 120.19$, M element, 449-61; sample D/E, $\times 170$. 20, S element, 449-62; sample D/E, $\times 250$. 


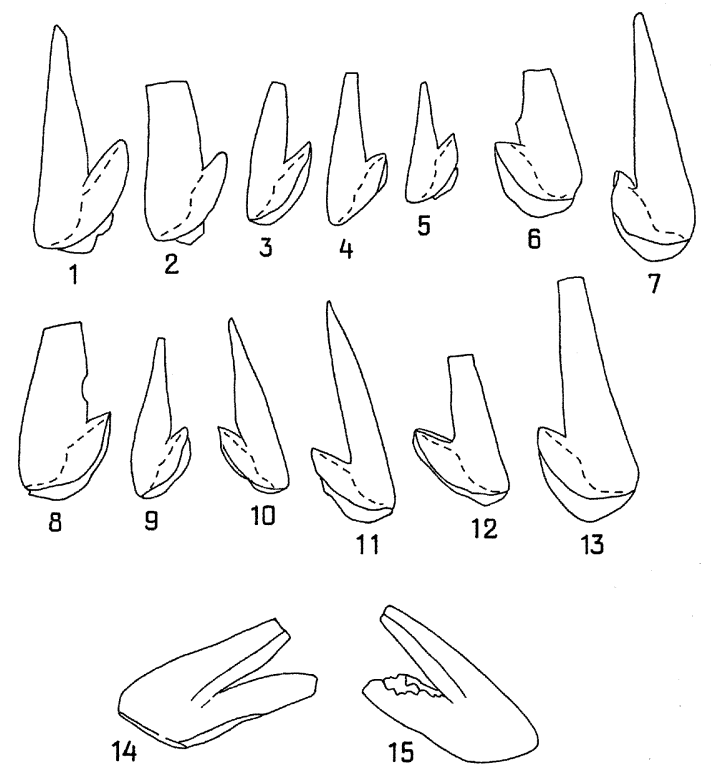

Fig. 6. Camera lucida drawings of the M element of Drepanoistodus. 1-13, D. suberectus (Branson \& Mehl); $14,15, D$. aff. D. venustus Stauffer. $1-7$, sample $C^{1} ; 8-10$, sample D/E; 11 , sample E/F; 12 , 13 , sample $\mathrm{H}_{1} / \mathrm{H}_{2}{ }^{1} ; 14$, sample $\mathrm{G}_{2}{ }^{1} ; 15$, sample $\mathrm{F}_{2} / \mathrm{F}_{3}$.

the cusp and base is very sharp so that they become subparallel. The aboral margin has an obtuse corner one-third of the distance from the anterio-aboral angle. On the inner side of the cusp is a pronounced costa, the posterior margin of which may be sharp. The basal cavity is low, slightly expanded in the posterior part. The tip of the cavity is barely noticeable. The oral edge of the base and the anterior and posterior edges of the cusp are very sharp.

Family PROTOPANDERODONTIDAE Lindström, 1970

Genus Semiacontiodus Miller, 1969

Semiacontiodus carinatus Dzik, 1976

Plate V, figures $1-22$

1962 Paltodus n. sp.; Bergström, pp. 47, 48, pl. 1, figs 6-9, text-fig. 3D.

1962 Distacodus? falcatus Stauffer, 1935; Bergström, pp. 38, 39, pl. 1, fig. 15, text-fig. 3C.

1976 Semiacontiodus carinatus sp. n.; Dzik, p. 421, pl. XLI, figs 5, 6, textfig. $13 \mathrm{~m}-\mathrm{o}$.

2000 Staufferella polonica (Spassov \& Teller, 1963); Leslie, pp. 1141, 1142, figs 6.11-6.18. 
Remarks. Semiacontiodus carinatus was originally described from erratic boulders of Baltic origin occurring in northern Poland (Dzik 1976). The stratigraphic level was identified by the occurrence of the index species Eoplacognathus robustus and Pygodus serra in the same boulders. From the short original description and illustrations of Dzik (1976) it is possible to recognize three elements with sharpened margins: symmetrical element, asymmetrical element with one lateral keel, and asymmetrical element with two lateral keels. The original material of Scandodus polonicus Spassov \& Teller 1963 was from Ordovician limestones near the village of Mójcza in Poland. Dzik (1994) carried out a subsequent detailed study of the Mójcza section and identified Semiacontiodus longicostatus Drygant and a few specimens of Semiacontiodus cornuformis (Sergeeva). Scandodus polonicus was included in the synonymy of $S$. cornuformis with "cf." by Dzik (1994). The material of Staufferrella polonica in Leslie (2000) came from Fjäcka and Kårgärde (B. alobatus Subzone) in Sweden and from core 0639 in Estonia. Two elements of the four described by Leslie $-\mathrm{Sb}$ and $\mathrm{Sc}-$ are identical to the characteristically sharpened elements of S. carinatus. In the Kohtla section, Semiacontiodus carinatus is identified from the presence of specimens with "sharpened" edges. Landing et al. (1986) noted the similarity of their new species Scolopodus? praecornuformis to $S$. cornuformis Sergeeva. In our opinion, the former species is even more similar to $S$. carinatus and we agree with Landing et al. (1986, p. 1942) that they all may be part of a "natural grouping". In borehole sections in Estonia (Taga-Roostoja, Valga, Tartu) the range for S. cornuformis is from the upper part of the Volkhov Stage up to the Keila Stage (Põldvere et al. 1998; Viira \& Männik 1999; Männik 2001). The borehole material shows that $S$. carinatus replaces $S$. cornuformis gradually through the boundary interval between the Lasnamägi and Uhaku stages.

Description. Semiacontiodus carinatus is similar to $S$. cornuformis but differs in the "sharpened" nature of cusp edges, especially in $\mathrm{Pb}$ and Pc elements. There is also a difference in the more rounded cross-section of the base, which may often be bulbous. In S. carinatus elements are noticeably variable, especially in inclination of the cusp and in twisting of the element. Transitions between elements are observed. A basal cone is often preserved. The cusp is finely striated except along the wing-like edges and the aboral margin.

The Pa element has a recurved cusp, flexed to the inner side and laterally compressed, with a latero-posterior wing-like extension distally. The anterior edge is moderately rounded, with a low groove along the inner side. The base bulges, with an oval to rounded outline. The Pa element is similar to that of Semiacontiodus davidi Löfgren (1999, pl. 2, figs 6, 15, 19).

The $\mathrm{Pb}$ element is that illustrated by Dzik (1976, fig. 13n) and resembles specimens assigned to the Sb position of Staufferella polonica by Leslie (2000). The cusp is proclined to erect, rounded anteriorly, and with a sharp latero-posterior wing-like extension above the base. The anterior edge is rounded, sharpened in the basal part. Some specimens have a bulging base. The basal cavity outline is irregularly oval. 


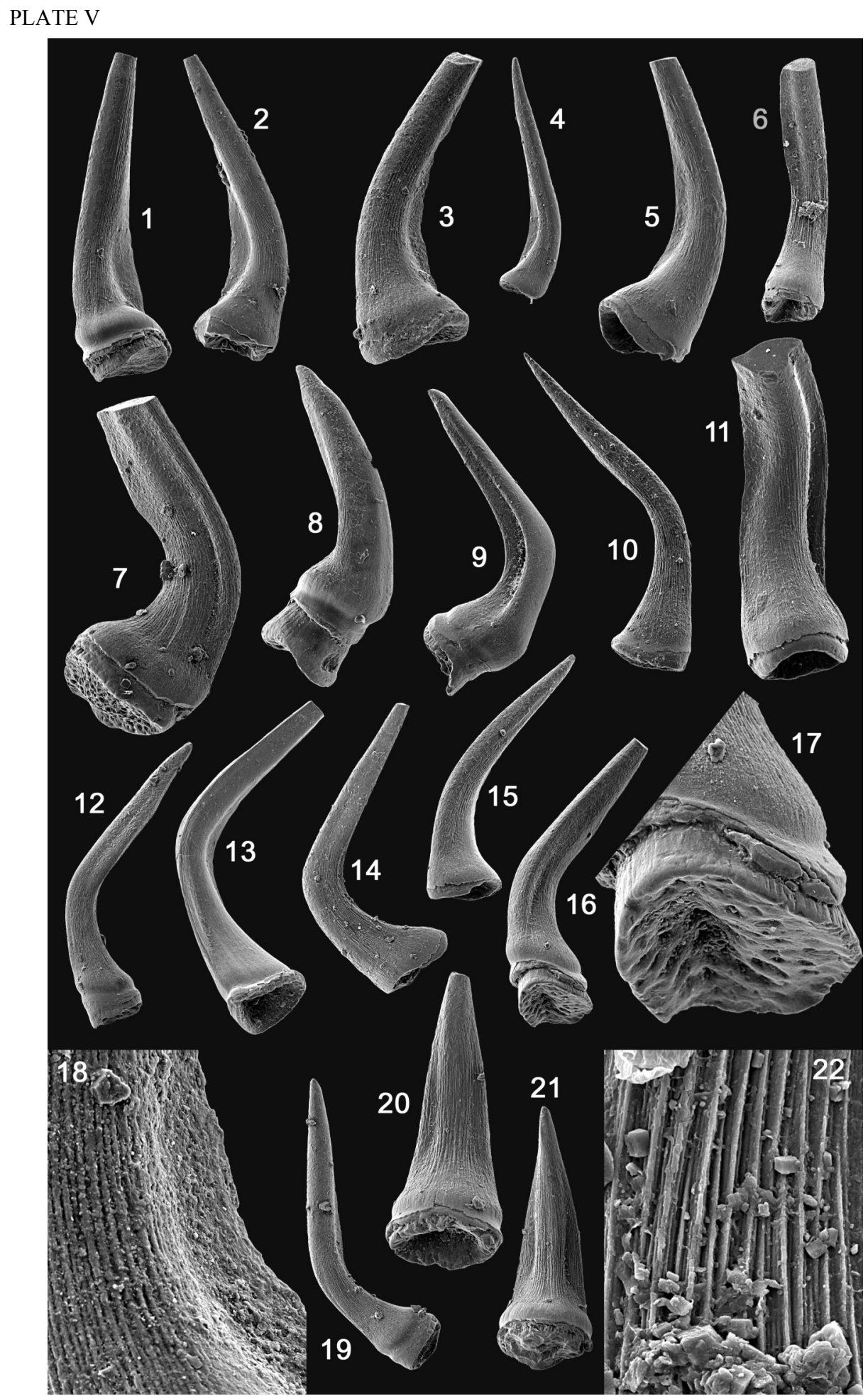


The Pc element has a proclined cusp with two sharp wing-like edges of different size. The element is rather strongly twisted. The aboral margin of the base is rounded, and the base itself is small.

The Sa element has a reclined to erect cusp with a rounded and deeply striated posterior face ( $\mathrm{Pl}$. V, figs 16, 17, 20-22). The anterior face is rounded, and the element is laterally flared, forming a high triangular outline in posterior view. On each side of the cusp on the posterior face is a low groove. The base bulges noticeably and has a rounded aboral outline.

The $\mathrm{Sb}$ element is similar to the $\mathrm{Sb}$ of $S$. cornuformis, with perhaps a narrower distal wing-like development. The cusp is proclined to erect, slightly twisted, with a sharp posterior edge. The base is rounded and rather long.

The Sc element has a proclined to erect cusp with two sharp latero-posterior edges which almost reach the aboral margin. The base is as long as the cusp or even longer.

Order PANDERODONTIDA Sweet, 1988

Family PANDERODONTIDAE Lindström, 1970

Genus Panderodus Ethington, 1959

Panderodus sulcatus (Fåhraeus, 1966)

Plate IV, figures 1-14

1966 Paltodus sulcatus n. sp.; Fåhraeus, p. 25, pl. III, figs 9a, 9b.

1966 Panderodus gracilis (Branson \& Mehl, 1933); Fåhraeus, p. 26, pl. III, figs $14 \mathrm{a}, 14 \mathrm{~b}$.

Remarks. This species was fully described by Löfgren (1978). The terminology used in the plate descriptions follows Sansom et al. (1994).

\section{Explanation of Plate V}

Figs 1-22. Semiacontiodus carinatus Dzik. 1, latero-posterior view, $\mathrm{Pb}$ element, 449-63; sample $\mathrm{C} / \mathrm{D}$ low, $\times 120$. 2, lateral view, $\mathrm{Pb}$ element, 449-64; sample $\mathrm{B} / \mathrm{C}, \times 120$. 3, lateral view, ?Pb element, 449-65; sample $\mathrm{K}^{3}, \times 150$. 4, lateral view, Pb element, 449-66; sample B/C, $\times 90$. 5, lateroposterior view, ?Pb element, 449-67, sample $\mathrm{K}^{3}, \times 150$. 6, latero-posterior view, Sb element, 449-68; sample D/E, $\times 120$. 7, lateral view, Pa element, 449-69; sample $\mathrm{K}^{3}, \times 120.8$, latero-anterior view, Sa element, 449-70; sample B/C, $\times 120$. 9, lateral view, Sa element, 449-71; sample $\mathrm{K}^{3}, \times 120$. 10 , lateral view, Sb element, 449-72, sample $\mathrm{K}^{3}, \times 120$. 11, posterior view, Pc element, 449-73; sample D/E, $\times 150$. 12, lateral view, Sb element, 449-74; sample $\mathrm{K}^{3}, \times 90.13$, posterio-lateral view, Sc element, 449-75; sample $\mathrm{K}^{3}, \times 120$. 14, lateral view, Sb element, 449-76; sample B/C, $\times 120$. 15 , lateral view, ?Pb element, 449-77; sample $\mathrm{K}^{3}, \times 120$. 16, 17, lateral view and base with basal filling, Sa element, 449-78; sample $\mathrm{K}^{3}, \times 150, \times 400.18$, 19, detail of cusp and lateral view, Sb element, 449-79, sample $\mathrm{C} / \mathrm{D}^{1}, \times 800, \times 90$. 20, posterior view, Sa element, 449-80; sample $\mathrm{K}^{3}$, $\times 150.21,22$, posterior view and close-up showing striation on the posterior face, Sa element, 449-81; sample $\mathrm{B} / \mathrm{C}, \times 150, \times 1600$. 


\section{ACKNOWLEDGEMENTS}

This paper is a contribution to IGCP Project 503. The work was funded by the Royal Society under a Joint Project with the FSU. S.C. acknowledges the support of a NERC studentship. V.V.'s research was supported by the Estonian Science Foundation grants Nos 5922 and 6127. The reviewers A. Löfgren and P. Männik are thanked for their remarks and corrections.

\section{REFERENCES}

Aldridge, R. J., Purnell, M. A., Gabott, S. E. \& Theron, J. N. 1995. The apparatus architecture and function of Promissum pulchrum Kovács-Endrödy (Conodonta, Upper Ordovician) and the prioniodontid plan. Philos. Trans. Roy. Soc. London, Ser. B, 347, 275-291.

Bauert, H. 1989. Discontinuity surfaces of possible microkarst origin in the Viivikonna Formation (Kukruse Stage, Middle Ordovician) of Estonia. Proc. Acad. Sci. Estonian SSR Geol., 38, $77-82$.

Bergström, S. M. 1962. Conodonts from the Ludibundus Limestone (Middle Ordovician) of the Tvären area (S.E. Sweden). Arkiv Mineral. Geol., 3, 1-61.

Bergström, S. M. 1971. Conodont biostratigraphy of the Middle and Upper Ordovician of Europe and Eastern North America. Geol. Soc. Amer. Mem., 127, 83-162.

Bergström, S. M. 1983. Biogeography, evolutionary relationships, and biostratigraphic significance of Ordovician platform conodonts. Fossils Strata, 15, 35-58.

Bergström, S. M. \& Orchard, M. J. 1985. Conodonts of the Cambrian and Ordovician systems from the British Isles. In A Stratigraphical Index of Conodonts (Higgins, A. C. \& Austin, R. L., eds), pp. 32-67. Ellis Horwood, Chichester, for British Micropalaeontological Society.

Bergström, S. M., Rhodes, F. H. T. \& Lindström, M. 1987. Conodont biostratigraphy of the Llanvirn-Llandeilo and Llandeilo-Caradoc Series boundaries in the Ordovician System of Wales and the Welsh Borderland. In Conodonts: Investigative Techniques and Applications (Austin, R. L., ed.), pp. 294-315. Ellis Horwood. Chichester, for British Micropalaeontological Society.

Bergström, S. M., Finney, S. C., Chen Xu, Palsson, C., Wang Zhi-hao \& Grahn, Y. 2000. A proposed global boundary stratotype for the base of the Upper Series of the Ordovician System: Fågelsång section, Scania, southern Sweden. Episodes, 23, 102-109.

Branson, E. B. \& Mehl, M. G. 1933. Conodont studies. Univ. Missouri Studies, 8, 77-167.

Donoghue, P. C. J., Forey, P. L. \& Aldridge, R. J. 2000. Conodont affinity and chordate phylogeny. Biol. Rev., 75, 191-251.

Dzik, J. 1976. Remarks on the evolution of Ordovician conodonts. Acta Palaeontol. Polonica, 21, 395-455.

Dzik, J. 1978. Conodont biostratigraphy and paleogeographical relations of the Ordovician Mójcza Limestone (Holy Cross Mts, Poland). Acta Palaeontol. Polonica, 23, 51-72.

Dzik, J. 1983. Biogeography, evolutionary relationships, and biostratigraphic significance of Ordovician platform conodonts. Fossils Strata, 15, 35-58.

Dzik, J. 1994. Conodonts of the Mójcza Limestone. Palaeontol. Polonica, 53, 43-128.

Ethington, R. L. 1959. Conodonts of the Ordovician Galena Formation. J. Paleontol., 33, 257-292.

Fåhraeus, L. E. 1966. Lower Viruan (Middle Ordovician) conodonts from the Gullhögen quarry, southern central Sweden. Sver. Geol. Unders., Ser. C, 610, 1-40.

Fåhraeus, L. E. \& Nowlan, G. S. 1978. Franconian (Late Cambrian) to early Champlainian (Middle Ordovician) conodonts from the Cow Head Group, western Newfoundland. J. Paleontol., 52, 444-471. 
Hadding, A. 1913. Undre Dicellograptusskiffern i Skåne jämte några därmed ekvivalenta bildningar. Lunds Univ. Arsskr., N. F., Afd. 2, 9, 15, 1-90.

Hamar, G. 1966. The Middle Ordovician of the Oslo region, Norway. 22. Preliminary report on conodonts from the Oslo-Asker and Ringerike districts. Norsk Geol. Tidsskr., 46, 27-83.

Hass, W. H. 1959. Conodonts from the Chappel Limestone of Texas. U. S. Geol. Surv. Prof. Pap. 294-J, 365-399.

Hints, L. 1997. Kukruse Stage. In Geology and Mineral Resources of Estonia (Raukas, A. \& Teedumäe, A., eds), pp. 71-72. Estonian Academy Publishers, Tallinn.

Kattai, V., Saadre, T. \& Savitski, L. 2000. Eesti põlevkivi: geoloogia, ressurss, kaevandamistingimused. Eesti Geoloogiakeskus, Tallinn.

Kõrts, A. 1992. Ordovician oil shale of Estonia - Origin and paleoecological characteristics. In Global Perspectives on Ordovician Geology (Webby, B. D. \& Laurie, J. R., eds), pp. 445454. Balkema, Rotterdam.

Kõrts, A. \& Einasto, R. 1990. Kohtla and Maidla quarries. In Field Meeting Estonia 1990, An Excursion Guidebook (Kaljo, D. \& Nestor, H., eds), pp. 145-148. Institute of Geology, Estonian Academy of Sciences, Tallinn.

Landing, E., Barnes, C. R. \& Stevens, R. K. 1986. Tempo of earliest Ordovician graptolite faunal succession: conodont-based correlations from the Tremadocian of Quebec. Can. J. Earth Sci., 23, 1928-1949.

Leslie, S. A. 2000. Mohawkian (Upper Ordovician) conodonts of eastern North America and Baltoscandia. J. Paleontol., 74, 1122-1147.

Lindström, M. 1970. A suprageneric taxonomy of the conodonts. Lethaia, 3, 427-445.

Lindström, M. 1971. Lower Ordovician conodonts of Europe. Geol. Soc. Amer. Mem., 127, 21-61.

Löfgren, A. 1978. Arenigian and Llanvirnian conodonts from Jämtland, northern Sweden. Fossils Strata, 13.

Löfgren, A. 1999. The Ordovician conodont Semiacontiodus cornuformis (Sergeeva, 1963) and related species in Baltoscandia. Geol. Palaeontol., 33, 71-91.

Männik, P. 2001. Distribution of conodonts. In Valga (10) Drill Core (Põldvere, A., ed.), Estonian Geol. Sections, 3, 10-12.

Männik, P. 2003. Distribution of Ordovician and Silurian conodonts. In Ruhnu (500) Drill Core (Põldvere, A., ed.), Estonian Geol. Sections, 5, 17-23.

Männik, P. \& Aldridge, R. J. 1989. Evolution, taxonomy and relationships of the Silurian conodont Pterospathodus. Palaeontology, 32, 893-906.

Männil, R. M. 1966. Istoriya razvitiya Baltijskogo bassejna v ordovike. Valgus, Tallinn (in Russian).

Männil, R. 1984. On the stratigraphic subdivision of the Kukruse Stage in the stratotype area. Proc. Acad. Sci. Estonian SSR Geol., 33, 46-54 (in Russian).

Männil, R. 1986. Stratigraphy of kukersite-bearing deposits $\mathrm{C}_{\mathrm{I}} \mathrm{b}-\mathrm{C}_{\mathrm{III}}$. In Geology of the KukersiteBearing Beds of the Baltic Oil Shale Basin (Puura, V., ed.), pp. 12-24. Valgus, Tallinn (in Russian).

Männil, R. 1990. The Ordovician of Estonia. In Field Meeting Estonia 1990. An Excursion Guidebook (Kaljo, D. \& Nestor, H., eds), pp. 11-20. Institute of Geology, Estonian Academy of Sciences, Tallinn.

Männil, R. \& Bauert, H. 1986. Geology of kukersite-bearing beds. In Geology of the KukersiteBearing Beds of the Baltic Oil Shale Basin (Puura, V., ed.), pp. 25-37. Valgus, Tallinn (in Russian).

Männil, R., Bauert, H. \& Puura, V. 1986. Peculiarities of kukersite accumulation. In Geology of the Kukersite-Bearing Beds of the Baltic Oil Shale Basin (Puura, V., ed.), pp. 48-54. Valgus, Tallinn (in Russian).

Miller, J. F. 1969. Conodont fauna of the Notch Peak Limestone (Cambro-Ordovician), House Range, Utah. J. Paleontol., 43, 413-439.

Nõlvak, J. 1997. Ordovician. Introduction. In Geology and Mineral Resources of Estonia (Raukas, A. \& Teedumäe, A., eds), pp. 54-55. Estonian Academy Publishers, Tallinn. 
Nõlvak, J. \& Goldman, D. 2004. Distribution of Nemagraptus in the East Baltic Ordovician. In WOGOGOB-2004 Conference Materials (Hints, O. \& Ainsaar, L., eds), pp. 77-78. Tartu University Press, Tartu.

Nõlvak, J. \& Grahn, Y. 1993. Ordovician chitinozoan zones from Baltoscandia. Rev. Palaeobot. Palynol., 79, 245-269.

Põldvere, A., Meidla, T., Bauert, G., Bauert, H. \& Stouge, S. 1998. Ordovician. In Tartu (453) Drill Core (Põldvere, A., ed.), Estonian Geol. Sections, 1, 11-17.

Purnell, M. A., Donoghue, P. C. J. \& Aldridge, R. J. 2000. Orientation and anatomical notation in conodonts. J. Paleontol., 74, 113-122.

Repetski, J. E., Purnell, M. A. \& Barrett, S. F. 1998. The apparatus structure of Phragmodus. In ECOS VII Abstracts, Bologna-Modena 1998 (Bagnoli, G., ed.), pp. 92-93. Tipografia Compositori Bologna.

Rõõmusoks, A. 1970. Stratigrafiya viruskoj i haryuskoj serij (ordovik) severnoj Éstonij. Valgus, Tallinn (in Russian).

Saadre, T. 1993. Middle and Upper Ordovician discontinuity surfaces in northern Estonia (zonally based on their impregation type). Bull. Geol. Surv. Estonia, 3/1, 33-39.

Saadre, T. \& Suuroja, K. 1993. Stratigraphy of the Kukruse Stage in Estonia. Bull. Geol. Surv. Estonia, 3/1, 25-32.

Sansom, I. J., Armstrong, H. A. \& Smith, M. P. 1994. The apparatus architecture of Panderodus and its implications for coniform conodont classification. Palaeontology, 37, 781-799.

Spassov, H. \& Teller, L. 1963. Conodonts from the Ordovician limestones near Mójcza village, in Górach Święntokrzyskich, Poland. Trav. Geol. Bulgarie, Ser. Paleontol., V, 75-87.

Stauffer, C. R. 1935. Conodonts of the Glenwood beds. Geol. Soc. Amer. Bull., 46, 125-168.

Sweet, W. C. 1981. Macromorphology of elements and apparatuses. In Treatise on Invertebrate Paleontology, W (Supplement 2 Conodonta) (Robinson, R. A., ed.), pp. W5-W20. The Geological Society of America, Inc. The University of Kansas.

Sweet, W. C. 1988. The Conodonta: Morphology, Taxonomy, Paleoecology, and Evolutionary History of a Long-Extinct Animal Phylum. Clarendon Press, Oxford.

Sweet, W. C. \& Schönlaub, H. P. 1975. Conodonts of the genus Oulodus Branson \& Mehl, 1933. Geol. Palaeontol., 9, 41-59.

Viira, V. 1967. Ordovician conodont succession in the Ohesaare core. ENSV Tead. Akad. Toim. Keemia Geol., 16, 319-329 (in Russian).

Viira, V. 1974. Konodonty ordovika Pribaltiki. Valgus, Tallinn (in Russian).

Viira, V. \& Männik, P. 1999. Distribution of conodonts. In Taga-Roostoja (25A) Drill Core (Põldvere, A., ed.), Estonian Geol. Sections, 2, 9-10.

Zhang, J. 1998. Conodonts from the Guniutan Formation (Llanvirnian) in Hubei and Hunan Provinces, south-central China. Acta Univ. Stockholmiensis, Stockholm Contrib. Geol., 46.

\title{
Viivikonna kihistu Kiviõli kihistiku (Ülem-Ordoviitsium) konodondid Kohtla läbilõikes Eestis
}

\author{
Viive Viira, Richard J. Aldridge ja Stephanie Curtis
}

Kiviõli kihistiku põlevkivi- ja lubjakivikihtide konodondi fauna sarnaneb samaealiste faunadega teistes regioonides ega sisalda endeemilisi taksoneid selles spetsiifilises kukersiidikuhje keskkonnas. Amorphognathus tvaerensis'e esinemise ja Pygodus anserinus'e puudumise põhjal võib järeldada, et Kukruse lademe alumine osa vastab A. tvaerensis'e biotsoonile ja et Ülem-Ordoviitsiumi alumine piir on Kukruse lademe alumisel piiril või sellest allpool. 